\title{
Health-Related Quality of Life of Experts Who Worked in Air Disasters in São Paulo, Brazil
}

\author{
Victor Alexandre Percinio Gianvecchio ${ }^{1}$, Daniel Romero Muñoz ${ }^{2}$, \\ Carmen Lucia Penteado Lancellotti ${ }^{1}$ \\ ${ }^{1}$ School of Medical Sciences, Santa Casa de Sao Paulo, São Paulo, Brazil \\ ${ }^{2}$ School of Medicine, São Paulo University, São Paulo, Brazil \\ Email: *victorgianvecchio@hotmail.com, danielmunoz@bol.com.br, luciapl@uol.com.br
}

How to cite this paper: Gianvecchio, V.A.P., Muñoz, D.R. and Lancellotti, C.L.P. (2018) Health-Related Quality of Life of Experts Who Worked in Air Disasters in São Paulo, Brazil. Journal of Behavioral and Brain Science, 8, 207-217.

https://doi.org/10.4236/jbbs.2018.85014

Received: March 2, 2018

Accepted: May 5, 2018

Published: May 8, 2018

Copyright () 2018 by authors and Scientific Research Publishing Inc. This work is licensed under the Creative Commons Attribution International License (CC BY 4.0).

http://creativecommons.org/licenses/by/4.0/

\begin{abstract}
Aim: To evaluate the influence of identifying victims of air disasters in São Paulo on experts' quality of life (QoL). Methods: QoL was evaluated using the abbreviated version of the World Health Organization (WHO) quality of life questionnaire (WHOQOL-bref). We assessed 29 forensic experts who worked in air disasters in São Paulo and 29 experts who have not worked. The results were analyzed with Student's $t$-tests; we compared the QoL scores of individuals at the time of the accident with their current QoL scores, and the scores of the control group were compared with the current scores of the disaster group. Results: Statistical analyses revealed a significant decrease in forensic expert QoL when they worked at the accident site, and this result was evident in all WHOQOL-bref domains. No significant difference was observed between the experts' current QoL scores and those of the control group. Conclusions: The identification of air disaster victims in the city of São Paulo significantly decreased expert health-related QoL (HRQoL) with regard to physical and psychological aspects, social relationships and environment domains. This disturbance on the QoL was not persistent over the years.
\end{abstract}

\section{Keywords}

Accidents, Aviation, Disasters, Medical Examiners, Quality of Life, Victims Identification

\section{Introduction}

Air accidents are one of the most feared types of mass disasters [1]. In Brazil, these disasters have been highly publicized in recent years, with the fall of a Fokker 100 in São Paulo in 1996 (99 victims), a mid-air collision between a Boeing 737 - 800 and a Legacy jet in 2006 (154 victims), the fall of an Airbus A320 in 
São Paulo in 2007 (199 victims), and the fall of an Air France Airbus A330-200 in 2009 (228 victims).

Mass disasters have a major impact on society, and air accidents, in particular, trigger massive social upheaval. The media contributes to this increased tension by repeatedly airing graphic footage from the scene [1] [2].

Air accidents require emergency measures of integrated teams of firemen, health professionals, and police officers. Victims who perish in large-scale air accidents are often dismembered and burned [3]. In these circumstances, the role of forensic experts is crucial [4].

These experts have to address the social commotion surrounding the accident, deal with pressure from the media and the authorities, and face difficulties inherent to their area of expertise which are the identification of dismembered and burned bodies of the victims. The workload in these circumstances far exceeds the usual because it is 24 hours a day, 7 days a week, until the situation is resolved [4] [5]. All of these aspects alter the lifestyle and routines of these experts.

The World Health Organization (WHO) defines quality of life (QoL) as "individuals perception of their position in life in the context of the culture and value systems in which they live and in relation to their goals, expectations, standards and concerns" [6].

Few studies have assessed the influence on the QoL of professionals who have worked in mass disasters [2] [7]. Firefighters and police officers are the most studied populations. No reports have been published regarding the effects on forensic experts.

The goal of the current study was to evaluate the influence of identifying victims of air disasters in São Paulo on experts' quality of life (QoL).

\section{Method}

\subsection{Individuals}

A cross-sectional study was performed with forensic experts who worked in the identification of victims of air disasters that occurred in São Paulo city in 1996 and 2007. São Paulo city is the capital of São Paulo State in Brazil; is the sixth most populated city in the world, with approximately 11 million inhabitants, and its metropolitan area is the fourth largest urban agglomeration in the world with over 19 million inhabitants [8].

A number of 29 forensic experts who have worked on disasters that occurred in São Paulo were contacted and voluntarily participated in this research. These represent almost all experts, but it is impossible to be sure of the number because of the time elapsed between the first accident and the research. The same number of forensic experts (29) who had never identified air accident victims was included as a control group.

\subsection{Data Collection and Instrument}

The data were collected through interviews, and health-related QoL was assessed 
with the abbreviated version of the instrument employed by the WHO to measure QoL (WHOQOL-bref), which was previously validated in Brazil [9]. The instrument consists of 26 questions that cover four QoL domains (physical, psychological, social relationships, and environment) that range from 0 (lowest QoL) to 100 points (highest QoL).

Each forensic experts who have worked on disasters answered the WHOQOL-bref twice, one related to the period they worked at the accident (group A1) and the other related to their current QoL (at least five years after the accident-group A2). The control group answered the questionnaire with regard to their current QoL (group C). The scores were calculated according to WHOQOL-bref guidelines.

\subsection{Statistical Analysis}

The results were analyzed using Student's $t$-tests, and the current QoL scores of the experts (group A2) were compared with their scores at the period of the accident (group A1), as well as with the scores of the control group (group C). Differences were considered statistically significant when $\mathrm{p}<0.05$. All statistical analyses were performed with SPSS ${ }^{\circledR}$ software, version 16.0 (SPSS Inc. Chicago, IL, USA).

The study was approved by Human Research Ethics Committee of the Irmandade da Santa Casa de Misericórdia de São Paulo, filed under number 22/2012. Participants consent were obtained, and the anonymity was preserved.

\section{Results}

Statistical analysis revealed significantly lower QoL scores in all four domains of the WHOQOL-bref at the period that experts worked at the accident sites (group A1) than their current QoL scores (group A2). Table 1 shows the forensic experts' QoL scores in these two situations.

Table 2 shows the current QoL scores for the expert (group A2) and control group (group C). We did not observe any significant differences between these groups.

Table 1. Statistical analysis of the forensic experts QoL scores in all domains of the WHOQOL-bref, at the period they worked at the accident sites (group A1) compared to the present (group A2).

\begin{tabular}{cccccc}
\hline \multirow{2}{*}{ Domains } & \multicolumn{2}{c}{ Mean } & \multicolumn{2}{c}{ Standard Deviation } & \multirow{2}{*}{ p-value } \\
\cline { 2 - 5 } & Group A1 & Group A2 & Group A1 & Group A2 & \\
\hline Physical & 66.3 & 75.9 & 16.3 & 14.2 & $\mathbf{0 . 0 0 2}^{*}$ \\
Psychological & 66.8 & 76.6 & 12.8 & 11.5 & $<0.001^{*}$ \\
Social relationships & 58.0 & 70.1 & 15.7 & 15.2 & $\mathbf{0 . 0 0 2}^{*}$ \\
Environment & 53.6 & 70.4 & 11.5 & 14.4 & $<\mathbf{0 . 0 0 1}^{*}$ \\
General QoL & 11.0 & 15.4 & 3.2 & 2.4 & $<\mathbf{0 . 0 0 1}^{*}$ \\
\hline
\end{tabular}

${ }^{*}$ significance. 
Table 2. Statistical analysis of the current QoL scores of the forensic experts (group A2) and the forensic experts control group (group C), in all domains of the WHOQOL-bref.

\begin{tabular}{cccccc}
\hline \multirow{2}{*}{ Domains } & \multicolumn{2}{c}{ Mean } & \multicolumn{2}{c}{ Standard Deviation } & \multirow{2}{*}{ p-value } \\
\cline { 2 - 5 } & Group A2 & Group C & Group A2 & Group C & \\
\hline Physical & 75.9 & 76.5 & 14.2 & 16.0 & 0.877 \\
Psychological & 76.6 & 74.9 & 11.5 & 11.5 & 0.572 \\
Social relationships & 70.1 & 74.4 & 15.2 & 16.2 & 0.300 \\
Environment & 70.4 & 74.1 & 14.4 & 13.1 & 0.301 \\
General QoL & 15.4 & 14.3 & 2.4 & 3.4 & 0.135 \\
\hline
\end{tabular}

A comparative analysis of the average of every WHOQOL-bref question of the questionnaires answered by the experts (group A1 and group A2) was performed to determine how each facet contained in the WHOQOL-bref had an effect on QoL. Significant changes were observed in question 5 (lack of positive feelings), question 9 (lack of healthy conditions in the physical environment), question 13 (lack of information), question 14 (lack of leisure opportunities), question 16 (lack of sleep), question 21 (dissatisfaction with sexual life), question 22 (dissatisfaction with personal relationships), and question 26 (presence of negative feelings). These results were depicted in Table 3, with the means and standard deviations of responses to these questions.

\section{Discussion}

In recent years, there has been increased scientific and social interest regarding the consequences that working at mass disasters has on professionals' health. These workers complete many stressful tasks during the execution of their work, including collecting bodies and body parts and identifying victims [10] [11].

Conditions such as post-traumatic stress disorder, depression, and chronic fatigue are reported in firefighters and police officers who have worked in disasters [10] [11] [12] [13] [14]. The health damage caused by their professional activities could also influence their QoL.

Slottje et al. [2] evaluated the QoL of firefighters and police officers exposed to a Dutch air disaster that had occurred 8.5 years before and concluded that these emergency responders exhibited decreased QoL, even after many years. Voelker et al. [15] evaluated soldiers who worked in the first Gulf War and found that it persistently negatively impacted their QoL.

Similarly, our results also demonstrated a decrease in the QoL of forensic experts who worked to identify victims of air accidents that occurred in the city of São Paulo. However, unlike other professional groups, the negative influence on QoL was not persistent for forensic experts; their current scores were not significantly different from those of the control group.

Chen et al. [7] verified a decrease in QoL of firefighters in Kaohsiung City, Taiwan and showed that the presence of sleep disorders significantly affected physical and mental aspects of QoL. 
Table 3. Comparative analysis of the average of each question of the two WHOQOL-bref questionnaires answered by the forensic experts, one related to the period they worked at the accident (group A1) and other with regard to the present (group A2).

\begin{tabular}{|c|c|c|c|c|c|}
\hline \multirow{2}{*}{ Questions } & \multicolumn{2}{|c|}{ Mean } & \multicolumn{2}{|c|}{ Standard Deviation } & \multirow{2}{*}{ p-value } \\
\hline & Group A1 & Group A2 & Group A1 & Group A2 & \\
\hline Q3 & 1.72 & 1.74 & 0.96 & 1.02 & 0.950 \\
\hline Q4 & 1.52 & 1.78 & 0.91 & 1.01 & 0.315 \\
\hline Q5 & 2.14 & 3.74 & 0.95 & 0.53 & $<0.001^{*}$ \\
\hline Q6 & 4.59 & 4.30 & 0.50 & 0.67 & 0.070 \\
\hline Q7 & 4.17 & 3.85 & 0.76 & 0.72 & 0.110 \\
\hline Q8 & 3.76 & 3.56 & 0.87 & 0.89 & 0.393 \\
\hline Q9 & 1.76 & 3.44 & 0.58 & 0.64 & $<0.001^{*}$ \\
\hline Q10 & 3.69 & 3.78 & 1.00 & 0.70 & 0.706 \\
\hline Q11 & 3.76 & 4.15 & 0.99 & 0.82 & 0.115 \\
\hline Q12 & 3.48 & 3.93 & 0.83 & 0.92 & 0.063 \\
\hline Q13 & 2.86 & 3.89 & 1.16 & 0.97 & $<0.001^{*}$ \\
\hline Q14 & 1.62 & 3.70 & 0.49 & 0.78 & $<0.001^{*}$ \\
\hline Q15 & 4.17 & 4.48 & 0.89 & 0.58 & 0.132 \\
\hline Q16 & 1.93 & 3.78 & 0.65 & 0.70 & $<0.001^{*}$ \\
\hline Q17 & 3.21 & 3.67 & 1.05 & 0.68 & 0.058 \\
\hline Q18 & 3.79 & 3.85 & 1.01 & 0.91 & 0.820 \\
\hline Q19 & 4.00 & 3.96 & 0.96 & 0.85 & 0.880 \\
\hline Q20 & 3.38 & 3.85 & 1.24 & 0.72 & 0.089 \\
\hline Q21 & 2.21 & 3.63 & 0.77 & 0.56 & $<0.001^{*}$ \\
\hline Q22 & 4.38 & 3.89 & 0.62 & 0.85 & $0.016^{*}$ \\
\hline Q23 & 4.34 & 4.19 & 0.72 & 0.62 & 0.380 \\
\hline Q24 & 3.69 & 3.89 & 1.04 & 0.85 & 0.437 \\
\hline Q25 & 3.62 & 3.74 & 1.05 & 1.02 & 0.667 \\
\hline Q26 & 2.62 & 1.81 & 0.94 & 0.56 & $<0.001^{*}$ \\
\hline
\end{tabular}

*significance.

In our research, we individually analyzed each question of the WHOQOL-bref and found that lack of sleep (question 16) had a significant negative influence on the physical domain of QoL, similar to what was observed in Taiwanese firefighters. Other aspects that had a significant negative influence on the experts' QoL were the lack of positive feelings (question 5); the presence of negative feelings (question 26); dissatisfaction with their sexual life and with their personal relationships (questions 21 and 22); and the lack of healthy conditions in the physical environment, information, and leisure opportunities (questions 9, 13 and 14). 
Exposure to violent deaths and dealing with corpses and body parts are associated with mental health problems [4] [14] [16]. Although forensic experts were used to dealing with corpses, massive exposure over several consecutive days may have contributed to the decreased QoL at the period of the accident.

Some limitations must be taken into consideration when interpreting the results of our study. A larger number of individuals would be preferable to increase the confidence interval. Nevertheless, identification of human remains is very specific and only performed by a small number of qualified professionals. In our research, all contacted forensic experts accepted the invitation to participate of the study and answered the questionnaire. The time elapsed between the accident and the research could be considered a bias because of difficulty in remembering previously occurring facts; however, it is not possible to plan a prospective study for these situations. We used a validated QoL instrument that did not have specific questions regarding the air accident, which may minimize this bias.

\section{Conclusion}

The findings of this study showed that the work of identifying victims of air disasters that occurred in São Paulo caused a significant decrease in HRQoL of forensic experts in physical, psychological, social relationships, and environment domains. This disturbance was not persistent over time. Some measures could be adopted to minimize this influence during the performance of such work, such as performing different activities, taking frequent rest breaks, and ensuring the presence of a team for psychological support and support for sleep quality improvement. Further studies should be conducted to analyze the influence on the QoL of professionals who worked to identify air accident victims but did not deal directly with corpses.

\section{Competing Interests}

The authors declare that they have no conflict of interest.

\section{Funding}

This research did not receive any specific grant from funding agencies in the public, commercial, or not-for-profit sectors.

\section{References}

[1] Donker, G.A., Yzermans, C.J., Spreeuwenberg, P. and van der Zee, J. (2002) Symptom Attribution after a Plane Crash: Comparison between Self-Reported Symptoms and GP Records. The British Journal of General Practice, 52, 917-922.

[2] Slottje, P., Twisk, J.W., Smidt, N., Huizink, A.C., Witteveen, A.B., van Mechelen, W. and Smid, T. (2007) Health-Related Quality of Life of Firefighters and Police Officers 8.5 Years after the Air Disaster in Amsterdam. Quality of Life Research, 16, 239-252. https://doi.org/10.1007/s11136-006-9006-2

[3] Schmeling, A., Geserick, G. and Wirth, I. (2010) Medicolegal Identification of Vic- 
tims in Mass Disasters Using the Example of Aircraft Accidents. Archiv für Kriminologie, 226, 24-37.

[4] Ursano, R.J., Fullerton, C.S., Vance, K. and Kao, T.C. (1999) Posttraumatic Stress Disorder and Identification in Disaster Workers. American Journal of Psychiatry, 156, 353-359.

[5] Berríos-Torres, S.I., Greenko, J.A., Phillips, M., Miller, J.R., Treadwell, T. and Ikeda, R.M. (2003) World Trade Center Rescue Worker Injury and Illness Surveillance, New York, 2001. American Journal of Preventive Medicine, 25, 79-87. https://doi.org/10.1016/S0749-3797(03)00110-7

[6] The WHOQOL Group (1995) The World Health Organization Quality of Life Assessment (WHOQOL): Position Paper from the World Health Organization. Social Science \& Medicine, 41, 1403-1410. https://doi.org/10.1016/0277-9536(95)00112-K

[7] Chen, Y.S., Chen, M.C., Chou, F.H., Sun, F.C., Chen, P.C., Tsai, K.Y. and Chao, S.S. (2007) The Relationship between Quality of Life and Posttraumatic Stress Disorder or Major Depression for Firefighters in Kaohsiung, Taiwan. Quality of Life Research, 16, 1289-1297. https://doi.org/10.1007/s11136-007-9248-7

[8] Instituto Brasileiro de Geografia e Estatística (IBGE) (2010) Censo 2010-São Paulo.

http://www.ibge.gov.br/home/estatistica/populacao/censo2010/tabelas_pdf/total_po pulacao_sao_paulo.pdf

[9] Fleck, M.P., Louzada, S., Xavier, M., Chachamovich, E., Vieira, G., Santos, L. and Pinzon, V. (2000) Application of the Portuguese Version of the Abbreviated Instrument of Quality Life WHOQOL-bref. Revista de Saúde Pública, 34, 178-183. https://doi.org/10.1590/S0034-89102000000200012

[10] Fullerton, C.S., Ursano, R.J. and Wang, L. (2004) Acute Stress Disorder, Posttraumatic Stress Disorder, and Depression in Disaster or Rescue Workers. American Journal of Psychiatry, 161, 1370-1376. https://doi.org/10.1176/appi.ajp.161.8.1370

[11] Stellman, J.M., Smith, R.P., Katz, C.L., Sharma, V., Charney, D.S., Herbert, R., Moline, J., Luft, B.J., Markowitz, S., Udasin, I., Harrison, D., Baron, S., Landrigan, P.J., Levin, S.M. and Southwick, S. (2008) Enduring Mental Health Morbidity and Social Function Impairment in World Trade Center Rescue, Recovery, and Cleanup Workers: The Psychological Dimension of an Environmental Health Disaster. Environmental Health Perspectives, 116, 1248-1253.

https://doi.org/10.1289/ehp.11164

[12] Huizink, A.C., Slottje, P., Witteveen, A.B., Bijlsma, J.A., Twisk, J.W., Smidt, N., Bramsen, I., van Mechelen, W., van der Ploeg, H.M., Bouter, L.M. and Smid, T. (2006) Long Term Health Complaints Following the Amsterdam Air Disaster in Police Officers and Fire-Fighters. Occupational and Environmental Medicine, 63, 657-662. https://doi.org/10.1136/oem.2005.024687

[13] Perrin, M.A., Di Grande, L., Wheeler, K., Thorpe, L., Farfel, M. and Brackbill, R. (2007) Differences in PTSD Prevalence and Associated Risk Factors among World Trade Center Disaster Rescue and Recovery Workers. American Journal of Psychiatry, 164, 1385-1394. https://doi.org/10.1176/appi.ajp.2007.06101645

[14] Witteveen, A.B., Bramsen, I., Twisk, J.W., Huizink, A.C., Slottje, P., Smid, T. and Van Der Ploeg, H.M. (2007) Psychological Distress of Rescue Workers Eight and One-Half Years after Professional Involvement in the Amsterdam Air Disaster. Journal of Nervous and Mental Disease, 195, 31-40. https://doi.org/10.1097/01.nmd.0000252010.19753.19

[15] Voelker, M.D., Saag, K.G., Schwartz, D.A., Chrischilles, E., Clarke, W.R., Woolson, 
R.F. and Doebbeling, B.N. (2002) Health-Related Quality of Life in Gulf War Era Military Personnel. American Journal of Epidemiology, 155, 899-907.

https://doi.org/10.1093/aje/155.10.899

[16] Thormar, S.B., Gersons, B.P., Juen, B., Marschang, A., Djakababa, M.N. and Olff, M. (2010) The Mental Health Impact of Volunteering in a Disaster Setting: A Review. Journal of Nervous and Mental Disease, 198, 529-538.

https://doi.org/10.1097/NMD.0b013e3181ea1fa9 


\section{WHOQOL-BREF}

The following questions ask how you feel about your quality of life, health, or other areas of your life. I will read out each question to you, along with the response options. Please choose the answer that appears most appropriate. If you are unsure about which response to give to a question, the first response you think of is often the best one.

Please keep in mind your standards, hopes, pleasures and concerns. We ask that you think about your life in the last four weeks.

\begin{tabular}{|l|l|c|c|c|c|c|}
\hline & Very poor & Poor & $\begin{array}{c}\text { Neither poor } \\
\text { nor good }\end{array}$ & Good & Very good \\
\hline 1. & $\begin{array}{l}\text { How would you rate your } \\
\text { quality of life? }\end{array}$ & 1 & 2 & 3 & 4 & 5 \\
\hline
\end{tabular}

\begin{tabular}{|l|l|c|c|c|c|c|}
\hline & $\begin{array}{c}\text { Very } \\
\text { dissatisfied }\end{array}$ & Dissatisfied & $\begin{array}{c}\text { Neither } \\
\text { satisfied nor } \\
\text { dissatisfied }\end{array}$ & Satisfied & $\begin{array}{c}\text { Very } \\
\text { satisfied }\end{array}$ \\
\hline 2. & $\begin{array}{l}\text { How satisfied are you with your } \\
\text { health? }\end{array}$ & 1 & 2 & 3 & 4 & 5 \\
\hline
\end{tabular}

The following questions ask about how much you have experienced certain things in the last four weeks.

\begin{tabular}{|l|l|c|c|c|c|c|}
\hline & Not at all & A little & $\begin{array}{c}\text { A moderate } \\
\text { amount }\end{array}$ & Very much & $\begin{array}{c}\text { An extreme } \\
\text { amount }\end{array}$ \\
\hline 3. & $\begin{array}{l}\text { To what extent do you feel that } \\
\text { physical pain prevents you } \\
\text { from } \\
\text { doing what you need to do? }\end{array}$ & 5 & 4 & 3 & 2 & 1 \\
\hline 4. & $\begin{array}{l}\text { How much do you need any } \\
\text { medical treatment to function } \\
\text { in your daily life? }\end{array}$ & 5 & 4 & 3 & 2 & 1 \\
\hline 5. & How much do you enjoy life? & 1 & 2 & 3 & 4 & 5 \\
\hline 6. & $\begin{array}{l}\text { To what extent do you feel your } \\
\text { life to be meaningful? }\end{array}$ & 1 & 2 & 3 & 4 & 5 \\
\hline
\end{tabular}

\begin{tabular}{|l|l|c|c|c|c|c|}
\hline & Not at all & A little & $\begin{array}{c}\text { A moderate } \\
\text { amount }\end{array}$ & Very much & Extremely \\
\hline 7. & $\begin{array}{l}\text { How well are you able to } \\
\text { concentrate? }\end{array}$ & 1 & 2 & 3 & 4 & 5 \\
\hline 8. & $\begin{array}{l}\text { How safe do you feel in your } \\
\text { daily life? }\end{array}$ & 1 & 2 & 3 & 4 & 5 \\
\hline 9. & $\begin{array}{l}\text { How healthy is your physical } \\
\text { environment? }\end{array}$ & 1 & 2 & 3 & 4 & 5 \\
\hline
\end{tabular}


The following questions ask about how completely you experience or were able to do certain things in the last four weeks.

\begin{tabular}{|l|l|c|c|c|c|c|}
\hline & & Not at all & A little & Moderately & Mostly & Completely \\
\hline 10. & $\begin{array}{l}\text { Do you have enough energy for } \\
\text { everyday life? }\end{array}$ & 1 & 2 & 3 & 4 & 5 \\
\hline 11. & $\begin{array}{l}\text { Are you able to accept your } \\
\text { bodily appearance? }\end{array}$ & 1 & 2 & 3 & 4 & 5 \\
\hline 12. & $\begin{array}{l}\text { Have you enough money to } \\
\text { meet your needs? }\end{array}$ & 1 & 2 & 3 & 4 & 5 \\
\hline 13. & $\begin{array}{l}\text { How available to you is the } \\
\text { information that you need in } \\
\text { your day-to-day life? }\end{array}$ & 1 & 2 & 3 & 4 & 5 \\
\hline 14. & $\begin{array}{l}\text { To what extent do you have the } \\
\text { opportunity for leisure } \\
\text { activities? }\end{array}$ & 1 & 2 & 3 & 4 & 5 \\
\hline
\end{tabular}

\begin{tabular}{|l|l|c|c|c|c|c|}
\hline & Very poor & Poor & $\begin{array}{c}\text { Neither poor } \\
\text { nor good }\end{array}$ & Good & Very good \\
\hline 15. & $\begin{array}{l}\text { How well are you able to get } \\
\text { around? }\end{array}$ & 1 & 2 & 3 & 4 & 5 \\
\hline
\end{tabular}

\begin{tabular}{|l|l|c|c|c|c|c|}
\hline & & $\begin{array}{c}\text { Very } \\
\text { dissatisfied }\end{array}$ & Dissatisfied & $\begin{array}{c}\text { Neither } \\
\text { satisfied nor } \\
\text { dissatisfied }\end{array}$ & Satisfied & $\begin{array}{c}\text { Very } \\
\text { satisfied }\end{array}$ \\
\hline 16. & $\begin{array}{l}\text { How satisfied are you with your } \\
\text { sleep? }\end{array}$ & 1 & 2 & 3 & 4 & 5 \\
\hline 17. & $\begin{array}{l}\text { How satisfied are you with } \\
\text { your ability to perform your } \\
\text { daily living activities? }\end{array}$ & 1 & 2 & 3 & 4 & 5 \\
\hline 18. & $\begin{array}{l}\text { How satisfied are you with } \\
\text { your capacity for work? }\end{array}$ & 1 & 2 & 3 & 4 & 5 \\
\hline 19. & $\begin{array}{l}\text { How satisfied are you with } \\
\text { yourself? }\end{array}$ & 1 & 2 & 3 & 4 & 5 \\
\hline
\end{tabular}




\begin{tabular}{|l|l|c|c|c|c|c|}
\hline 20. & $\begin{array}{l}\text { How satisfied are you with your } \\
\text { personal relationships? }\end{array}$ & 1 & 2 & 3 & 4 & 5 \\
\hline 21. & $\begin{array}{l}\text { How satisfied are you with } \\
\text { your sex life? }\end{array}$ & 1 & 2 & 3 & 4 & 5 \\
\hline 22. & $\begin{array}{l}\text { How satisfied are you with the } \\
\text { support you get from your } \\
\text { friends? }\end{array}$ & 1 & 2 & 3 & 4 & 5 \\
\hline 23. & $\begin{array}{l}\text { How satisfied are you with the } \\
\text { conditions of your living place? }\end{array}$ & 1 & 2 & 3 & 4 & 5 \\
\hline 24. & $\begin{array}{l}\text { How satisfied are you with your } \\
\text { access to health services? }\end{array}$ & 1 & 2 & 3 & 4 & 5 \\
\hline 25. & $\begin{array}{l}\text { How satisfied are you with } \\
\text { your transport? }\end{array}$ & 1 & 2 & 3 & 4 & 5 \\
\hline
\end{tabular}

The following question refers to how often you have felt or experienced certain things in the last four weeks.

\begin{tabular}{|c|c|c|c|c|c|c|}
\hline & & Never & Seldom & Quite often & Very often & Always \\
\hline 26. & $\begin{array}{l}\text { How often do you have } \\
\text { negative feelings such as blue } \\
\text { mood, despair, anxiety, } \\
\text { depression? }\end{array}$ & 5 & 4 & 3 & 2 & 1 \\
\hline
\end{tabular}

Do you have any comments about the assessment?

[The following table should be completed after the interview is finished]

\begin{tabular}{|c|c|c|c|c|c|}
\hline & \multirow{2}{*}{ Equations for computing domain scores } & \multirow{2}{*}{ Raw score } & \multicolumn{2}{|c|}{ Transformed scores* } \\
\hline & & & & $4-20$ & $0-100$ \\
\hline 27. & Domain 1 & $\begin{array}{l}(6-\mathrm{Q} 3)+(6-\mathrm{Q} 4)+\mathrm{Q} 10+\mathrm{Q} 15+\mathrm{Q} 16+\mathrm{Q} 17+\mathrm{Q} 18 \\
\square+\square+\square+\square+\square+\square+\square\end{array}$ & a. $=$ & $\mathrm{b}$ : & c: \\
\hline 28. & Domain 2 & $\begin{array}{l}\mathrm{Q} 5+\mathrm{Q} 6+\mathrm{Q} 7+\mathrm{Q} 11+\mathrm{Q} 19+(6-\mathrm{Q} 26) \\
\square+\square+\square+\square+\square+\square\end{array}$ & a. $=$ & $\mathrm{b}$ : & c: \\
\hline 29. & Domain 3 & $\begin{array}{l}\mathrm{Q} 20+\mathrm{Q} 21+\mathrm{Q} 22 \\
\square+\square+\square\end{array}$ & a. $=$ & $\mathrm{b}$ : & $\mathrm{c}$ : \\
\hline 30. & Domain 4 & $\begin{array}{l}\mathrm{Q} 8+\mathrm{Q} 9+\mathrm{Q} 12+\mathrm{Q} 13+\mathrm{Q} 14+\mathrm{Q} 23+\mathrm{Q} 24+\mathrm{Q} 25 \\
\square+\square+\square+\square+\square+\square+\square+\square\end{array}$ & a. $=$ & b: & c: \\
\hline
\end{tabular}

* See Procedures Manual, pages 13-15 